\title{
Pemanfaatan Algoritma ID3 sebagai Prediktor Kelulusan Mahasiswa AMIK Harapan Bangsa Surakarta
}

\author{
Ismail setiawan $^{1}$, Eko Purbiyanto ${ }^{2}$ \\ ${ }^{I}$ Dosen Tetap, AMIK Harapan Bangsa Surakarta \\ Alamat (Telp. (0271) 630029Fax. (0271) 630029; e-mail: ismailsetiawan@amikhb.ac.id)
}

\begin{abstract}
Student graduation is one of the assessments in the accreditation of study programs and institutions. The high rate of student graduation on time is directly proportional to the value of accreditation. Therefore each college tries its best to make its students graduate on time. Some strategies were finally carried out by universities such as making meetings with each Academic Advisor for each generation so that there was communication that could ultimately provide a solution if there was a potential for students who did not graduate on time. This study tries with another approach to predict students who have the potential to not pass on time. Computation calculations by paying attention to existing data are interesting topics to be discussed. The ID3 algorithm has the ability to make decision trees about a problem. The algorithm is used in this study and found that the first factor that needs to be considered in graduating students at AMIK Harapan Bangsa Surakarta is gender. Gender with male types has a greater percentage of graduates than women with a percentage of $60 \%$ versus $40 \%$. This can be a concern for AMIK Harapan Bangsa Surakarta towards final year students to detect as early as possible the potential of students who do not graduate on time.
\end{abstract}

Keywords - Students, graduate on time, ID3, AMIK Harapan Bangsa Surakarta, Gender.

Intisari- Kelulusan mahasiswa menjadi salah satu penilaian dalam akreditasi program studi maupun institusi. Tingginya angka kelulusan mahasiswa tepat waktu berbanding lurus dengan nilai akreditasi. Oleh karena itu masing-masing perguruan tinggi berusaha sebaik mungkin untuk membuat mahasiswanya lulus tepat waktu. Beberapa strategi akhirnya dilakukan oleh perguruan tinggi seperti membuat pertemuan dengan Pembimbing Akademik masing-masing angkatan sehingga terjadi komunikasi yang akhirnya dapat memberikan solusi jika terdeteksi adanya potensi mahasiswa yang tidak lulus tepat waktu. Penelitian ini mencoba dengan pendekatan lain untuk memprediksi mahasiswa yang memiliki potensi tidak lulus tepat waktu. Perhitungan komputasi dengan memperhatikan data yang telah ada sebelumnya menjadi topik yang menarik untuk dibahas. Algoritma ID3 memiliki kemampuan untuk membuat pohon keputusan mengenai sebuah masalah. Algoritma tersebut digunakan dalam penelitian ini dan didapatkan hasil bahwa faktor pertama yang perlu di perhatikan dalam kelulusan mahasiswa di AMIK Harapan Bangsa Surakarta adalah jenis kelamin. Kelamin dengan jenis pria memiliki prosentase lulus lebih besar dari wanita dengan prosentase $60 \%$ berbanding $40 \%$. Hal ini dapat menjadi perhatian bagi AMIK Harapan Bangsa Surakarta terhadap mahasiswa tingkat akhir untuk mendeteksi sedini mungkin potensi mahasiswa yang tidak lulus tepat waktu.

Kata kunci- Mahasiswwa, lulus tepat waktu, ID3, AMIK Harpan Bangsa Surakarta, Jenis Kelamin.

\section{Pendahuluan}

Berkembangnya ilmu pengetahuan dewasa ini menghasilkan bidang ilmu baru. Salah satu ilmu yang sedang berkembang pesat adalah teknologi informasi dan komunikasi (TIK). Perkembangan TIK menghasilkan banyak cabang ilmu baru diantarnya perancangan sistem informasi. Pada ilmu tersebut dibahas bagaimana membangun sistem informasi yang di desain khusus untuk mempermudah pekerjaan manusia dan menghurangi tingkat human error. Pengunaan aplikasi yang dihasilkan dari perancangan sistem informasi dewasa ini menjadi tren dan mampu meningkatkan nilai bisnis sebuah instansi (Setiawan et al., 2009).

Perguruan tinggi sebagai instansi Formal yang bergerak dibidang pendidikan memiliki mahasiswa sebagai komponen utama untuk berjalannya proses pendidikan. Perguruan tinggi dan swasta memiliki aturan yang berbeda pada perguruan tinggi negeri. Pada perguruan tinggi swasta Mahasiswa perlu dikelola secara baik sehingga mereka merasa nyaman hingga akhir masa kuliahnya (Andriani, 2012). Hal ini disebabkan perguruan tinggi swasta memerlukan sumbangan dari mahasiswa untuk melakukan kegiatan perkuliahan. Semakin banyak jumlah mahasiswanya maka semakin banyak fasilitas yang dapat dibangun untuk pelayanan.

Tidak dipungkiri terkadang mahasiswa tidak melanjutkan perkuliahan hingga selesai masa studinya. Banyak faktor yang menjadi alasan mahasiswa tidak melanjutkan kuliah hingga selesai (Nugroho, 2014). Hal ini menjadi persoalan tersendiri yang perlu di berikan perhatian khusus oleh kemahasiswaan. Selain berpengarung terhadap rasio jumlah mahasiswa terhadap dosen bagian keuangan juga akan merasakan dampaknya (Fakhrurrifqi \& Wardoyo, 2013). Kegiatan 
bisa tidak terlaksana dikarenakan tidak adanya anggaran yang masih bersumber dari sumbangan mahasiswa.

AMIK Harapan Bangsa Surakarta merupakan salah satu perguruan tinggi swasta di kota Surakarta. Perguruan tinggi tersebut memiliki satu program studi manajemen informatika dan jumlah mahasiswa sekitar 500 orang. Jumlah tersebut harus tetap dijaga sejak awal masuk hingga lulus untuk menjaga kestabilan keuangan instansi. Perlu perlakuan khusus kepada mahasiswa yang memiliki indikasi keluar di tengah jalan perkuliahan.

Peran utama data mining adalah melakukan estimasi, prediction, clasification, clustering dan association (Wu \& Kumar, 2009). Untuk mendeteksi mahasiswa yang memiliki kemungkinan untuk berhenti ditengah masa perkuliahan maka tugas prediksi cocok untuk mengolah datanya. Algoritma ID3 cocok untuk melakukan tugas prediksi (Slocum, 2012). Penelitian ini menggunakan algoritma ID3 untuk melakukan tugas prediksi mahasiswa yang memiliki kecenderungan untuk berhenti di tengah masa perkuliahan

\section{TINJAUAN PUSTAKA}

\section{Data Selection}

Pada tahap ini akan dilakukan pengumpulan data yang berhubungan dengan mahasiswa. Data diambil pada bian BAAK dan kemahasiswaan. Data tersebut akan di lakukan penggabungan atau sinkronisasi untuk kemudian dilakukan pemilihan atribut data yang sesuai dengan jalannya penelitian. Data yang telah mengalami proses seleksi akan disimpan dalam database tersendiri untuk proses selanjutnya.

\section{Pre-processing}

Data yang telah mengalami proses seleksi, data akan dibersihkan dari atribut yang tidak mendukung dalam proses prediksi (Elmande \& Widodo, 2012). Atribut yang dibersihkan adalah data yang memiliki duplikasi. Selain itu proses pre-processing akan melakukan perbaikan data yang salah ketik (tipografi). Berikutnya pada tahap ini akan dilakukan pemerkayaan data yang sudah ada dengan data atau informasi lain yang relevan untuk proses KDD.

\section{Transformation}

Tahap selanjutnya adalah pencarian fitur yang membantu dalam mecapai keputusan. Data yang terpilih pada proses ini akan dilakukan proses transofrmasi sehingga mudah terbaca oleh model yang dibangun nanti. Data pada tugas prediksi merupakan data nominal, oleh karena itu data dirubah menjadi nilai yang berbentuk nominal (Lavanya \& Rani, 2011).

\section{Data Mining}

Pada tahap ini data akan di pisah menjadi data learning dan data testing. Pada data learning algoritma akan membentuk model. Model tersebut diujikan menggunakan data testing untuk mengetahui tingkat akurasi dari model yang terbentuk (Ugulino, Cardador, \& Vega, 2012). Apabila nilai akurasi dari model yang terbentuk dirasa belum memuaskan maka perubahan indikator dan nilai penghitungan akan dilakukan pula pada tahap ini. Setelah model yang dibangun memiliki akurasi yang dirasa cukup memadai maka tahap ini dianggap selesai.

5. Interpretation

Tahap ini merupakan implementasi dari model yang telah berhasil dibangun. Model dikembangkan menggunakan aplikasi berbasis web, kemudian siap digunakan untuk melakukan tugas prediksi pada data baru yang diinputkan. Hasil dari prediksi dapat digunakan manajemen untuk mendukung keputusan

\section{III.HASIL DAN PEMBAHASAN}

\section{A. Data selection}

Proses awal dari pembahasan penelitian ini adalah membuat data selection atau pengumpulan data. Pengumpulan data dilakukan dengan mengambil dari bagian akademik. Untuk tahapannya dilakukan dua kali agar data yang digunakan semakin banyak dan proses komputasi menjadi semakin baik. Data awal disajikan pada tabel 1 sebagai berikut. 
Tabel 1. Data Akademik Siswa Angkatan 2012-2013

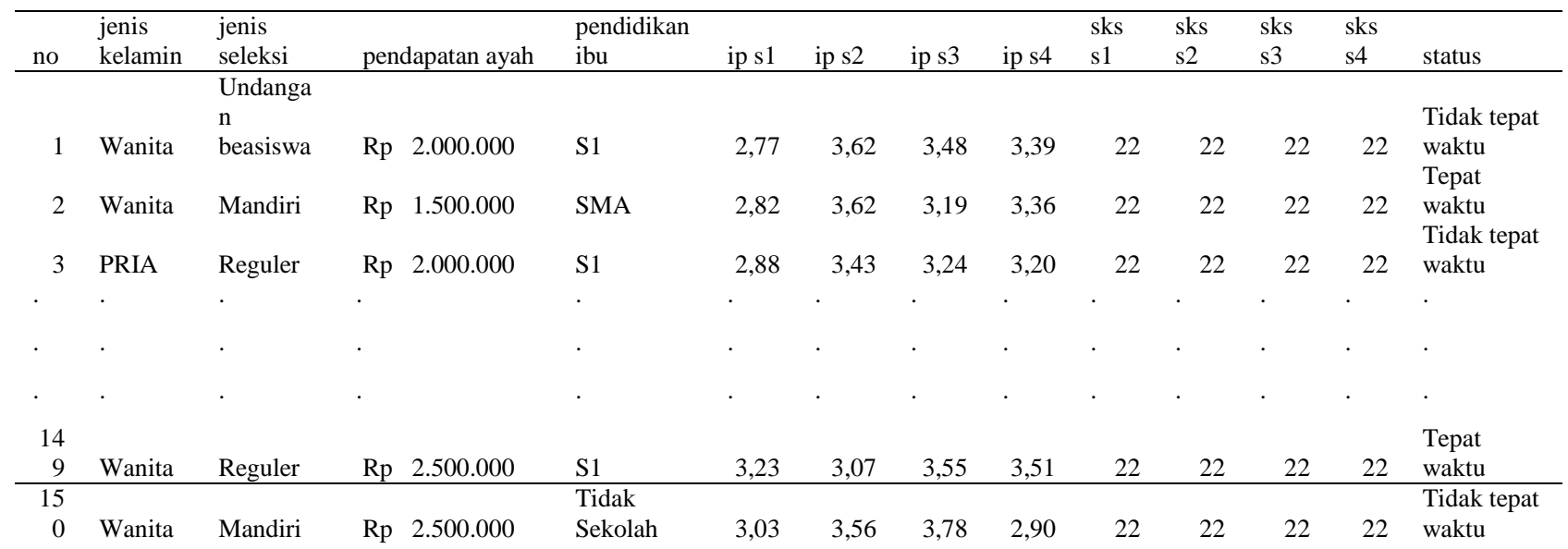

Tabel 3. Data Akademik Siswa Angkatan 2016-2017

\begin{tabular}{|c|c|c|c|c|c|c|c|c|c|c|c|c|c|}
\hline no & $\begin{array}{c}\text { jenis } \\
\text { kelamin }\end{array}$ & $\begin{array}{c}\text { jenis } \\
\text { seleksi }\end{array}$ & pendapatan ayah & $\begin{array}{c}\text { pendidikan } \\
\text { ibu }\end{array}$ & ip s1 & ip s2 & ip s3 & ip s4 & $\begin{array}{l}\text { sks } \\
\text { s1 }\end{array}$ & $\begin{array}{c}\text { sks } \\
\text { s2 }\end{array}$ & $\begin{array}{l}\text { sks } \\
\text { s3 }\end{array}$ & $\begin{array}{c}\text { sks } \\
\text { s4 }\end{array}$ & status \\
\hline 151 & Wanita & Mandiri & $\mathrm{Rp} \quad 1.000 .000$ & $\begin{array}{l}\text { Tidak } \\
\text { Sekolah } \\
\text { Tidak }\end{array}$ & 3,48 & 3,46 & 2,87 & 3,75 & 22 & 22 & 22 & 22 & $\begin{array}{l}\text { Tidak tepat } \\
\text { waktu } \\
\text { Tidak tepat }\end{array}$ \\
\hline 152 & Wanita & Mandiri & Rp 2.500 .000 & Sekolah & 3,01 & 3,26 & 2,86 & 3,63 & 22 & 22 & 22 & 22 & waktu \\
\hline 153 & Wanita & Mandiri & Rp 2.500 .000 & $\mathrm{~S} 1$ & 3,15 & 3,49 & 2,70 & 3,14 & 22 & 22 & 22 & 22 & waktu \\
\hline . & . & · & . & . & . & . & . & . & · & . & . & . & . \\
\hline . & . & . & . & . & . & . & . & . & . & . & . & . & . \\
\hline . & $\cdot$ & . & . & . & . & . & . & . & . & . & . & . & . \\
\hline 299 & Wanita & Mandiri & Rp 2.500 .000 & $\mathrm{~S} 1$ & 3,75 & 3,27 & 3,52 & 3,29 & 22 & 22 & 22 & 22 & $\begin{array}{l}\text { Tepat } \\
\text { waktu }\end{array}$ \\
\hline 300 & Wanita & Mandiri & Rp $\quad .500 .000$ & $\begin{array}{l}\text { Tidak } \\
\text { Sekolah }\end{array}$ & 3,45 & 2,84 & 3,63 & 3,57 & 22 & 22 & 22 & 22 & $\begin{array}{l}\text { Tepat } \\
\text { waktu }\end{array}$ \\
\hline
\end{tabular}

\section{B. Pre-processing}

Pada tahap ini dilakukan pembersihan data dan pelengkapan data yang tidak ada dalam tabel. Pada kasus ini data yang dikumpulkan telah terisi semua sehingga dapat dilakukan proses selanjutnya.

\section{Transformation}

Tahap ini seharusnya merubah data yang sifatnya belum nominal menjadi nominal sehingga mudah dalam mengambil keputusan. Kasus yang dibahas ini data sudah dalam bentuk nominal sehingga tidak perlu dilakukan transformasi data. Selanjutnya adalah proses data mining.

\section{Data mining}

Untuk pengolahan data dengan algoritma ID3 digunakan rumus dengan persamaan sebagai berikut.

Entropi $(\mathrm{S})=\sum_{j=1}^{k}-p_{j} \log _{2} p_{j}$

Dimana:

- S adalah himpunan (dataset) kasus

- k adalah banyaknya partisi $S$

- pj adalah probabilitas yang di dapat dari Sum(Ya) dibagi Total Kasus.

Setelah mendapat nilai entropi, pemilihan atribut dilakukan dengan nilai information gain terbesar.

Gain $(\mathrm{A})=\operatorname{entropi}(\mathrm{S})-\sum_{j=1}^{k} \frac{\left|S_{i}\right|}{|S|}-\operatorname{Entropi}\left(S_{i}\right)$ 
Dimana:

$\mathrm{S}=$ ruang (data) sample yang digunakan untuk training.

$\mathrm{A}=$ atribut.

$|\mathrm{Si}|=$ jumlah sample untuk nilai $\mathrm{V}$.

$|\mathrm{S}|=$ jumlah seluruh sample data.
Entropi $(\mathrm{Si})=$ entropy untuk sample-sample yang memiliki nilai $i$

Pada perhitungan pertama dalam pencarian gain didapati gain terbsesar dimiliki oleh jenis kelamin, sehingga jenis kelamin menjadi akar pertama dalam pohon keputusan.

TABEL 3

PROSES PENGHHITUNGAN GAIN

\begin{tabular}{|c|c|c|c|c|c|c|}
\hline node & & & jumlah kasus & Ya & tidak & entropi \\
\hline \multirow[t]{20}{*}{1} & total & & 301 & 145 & 156 & 0,999 \\
\hline & jenis kelamin & & & & & \\
\hline & & Wanita & 142 & 63 & 79 & 0,9908 \\
\hline & & PRIA & 159 & 82 & 77 & 0,9993 \\
\hline & jenis seleksi & & & & & \\
\hline & & Seleksi disekolah & 54 & 22 & 32 & 0,9751 \\
\hline & & Mandiri & 77 & 38 & 39 & 0,9999 \\
\hline & & Reguler & 123 & 62 & 61 & 1 \\
\hline & & Undangan beasiswa & 47 & 23 & 24 & 0,9997 \\
\hline & pendapatan ayah & & & & & \\
\hline & & 1000000 & 73 & 39 & 34 & 0,9966 \\
\hline & & 1500000 & 67 & 32 & 35 & 0,9986 \\
\hline & & 2000000 & 43 & 16 & 27 & 0,9523 \\
\hline & & 2500000 & 118 & 58 & 60 & 0,9998 \\
\hline & pendidikan ibu & & & & & \\
\hline & & tidak sekolah & 60 & 32 & 28 & 0,9968 \\
\hline & & sd & 51 & 29 & 22 & 0,9864 \\
\hline & & $\mathrm{smp}$ & 43 & 16 & 27 & 0,9523 \\
\hline & & sma & 35 & 12 & 23 & 0,9275 \\
\hline & & s1 & 112 & 56 & 56 & 1 \\
\hline
\end{tabular}

ip s1

\section{Dibawah Tiga}

Diatas Tiga

ip s2

ip s3

Dibawah Tiga

Diatas Tiga

Dibawah Tiga

Diatas Tiga

ip s4

Dibawah Tiga
Diatas Tiga

sks 1

0,995293484

0,003601698

0,007080234

0,017232093

4,00648E-06

$$
\begin{array}{rrrr}
91 & 44 & 47 & 0,9992 \\
210 & 101 & 109 & 0,999
\end{array}
$$

0,001439256

$$
\begin{array}{rrrr}
81 & 42 & 39 & 0,999 \\
220 & 103 & 117 & 0,9971
\end{array}
$$

0,000808849

$\begin{array}{rrrr}92 & 42 & 50 & 0,9945 \\ 209 & 106 & 103 & 0,9999\end{array}$

0,00033728

$\begin{array}{rrrr}78 & 39 & 39 & 1 \\ 223 & 106 & 117 & 0,9982\end{array}$

0,001507288

$\begin{array}{rrrrr}20 & 90 & 45 & 45 & 1 \\ 21 & 113 & 56 & 57 & 0,9999 \\ 22 & 98 & 44 & 54 & 0,9925\end{array}$


sks 2

sks 3

sks 4
0,007524501

$\begin{array}{rrrr}102 & 56 & 46 & 0,9931 \\ 94 & 40 & 54 & 0,9839 \\ 105 & 49 & 56 & 0,9968\end{array}$

0,018952103

$\begin{array}{rrrr}97 & 36 & 61 & 0,9515 \\ 109 & 55 & 54 & 0,9999 \\ 95 & 54 & 41 & 0,9864\end{array}$

0,013789212

$\begin{array}{rrrrr}20 & 108 & 58 & 50 & 0,996 \\ 21 & 99 & 38 & 61 & 0,9607 \\ 22 & 94 & 49 & 45 & 0,9987\end{array}$

Setelah dilakukan beberapa iterasi hingga semua kasus sudah memenuhi nilai lulus dan tidak lulus tepat waktu didapatkan hasil pohon keputusan sebagai berikut.

a. Wanita

|sks 4 - 20

|--| sks 320

|---|Ip S1 diatas tiga - Lulus tepat waktu / tidak

lulus tepat waktu

|----|Ip S1 Dibawah tiga - Lulus tepat waktu / tidak lulus tepat waktu

|--|Sks 321

|----|Ip S1 diatas tiga - Lulus tepat waktu / tidak lulus tepat waktu

|----|Ip S1 dibawah tiga - Lulus tepat waktu / tidak lulus tepat waktu

|--|Sks 322

|---|Ip S4 diatas tiga - Lulus tepat waktu

|----|Ip S4 dibawah tiga - Lulus tepat waktu

|SKS 4 - 21

|--|Pendapatan ayah 1000000

|----|pendidikan ibu Tidak Sekolah -tidak lulus tepat waktu

|----| pendidikan ibu SD - Lulus tepat waktu / tidak lulus tepat waktu

|----| pendidikan ibu SMP - Lulus tepat waktu /

tidak lulus tepat waktu
|----| pendidikan ibu SMA - Lulus tepat waktu

|----| pendidikan ibu S1 - tidak lulus tepat waktu |--|Pendapatan ayah 1500000

|----|pendidikan ibu Tidak Sekolah - Lulus tepat waktu / tidak lulus tepat waktu

|----|pendidikan ibu SD - tidak lulus tepat waktu

|----| pendidikan ibu SMP - tidak lulus tepat waktu

|----| pendidikan ibu SMA - tidak lulus tepat waktu

|---| pendidikan ibu S1 - tidak lulus tepat waktu

|--|Pendapatan ayah 2000000

|----|SKS 3 - 20 - tidak lulus tepat waktu

|----|SKS 3-21 - Lulus tepat waktu

|----|SKS 3 - 22 - Lulus tepat waktu

|--|Pendapatan ayah 2500000

|----|pendidikan ibu Tidak Sekolah -tidak lulus tepat waktu

|----| pendidikan ibu SD - Lulus tepat waktu

|----| pendidikan ibu SMP - Lulus tepat waktu

|----| pendidikan ibu SMA - tidak lulus tepat waktu

|----| pendidikan ibu S1 - Lulus tepat waktu

|sks $4-22$

|--| IP S4 - dibawah tiga - tidak lulus tepat waktu

|--| IP S4 - diatas 3 - Lulus tepat waktu / tidak lulus tepat waktu

b. Pria

| SKS $4-20$ 
|--| IP S1 - dibawah 3 - tidak lulus tepat waktu

|--| IP S1 - Diatas 3 - Lulus tepat waktu / tidak

lulus tepat waktu

|Sks $4-21$

|--|Seleksi mandiri - Lulus tepat waktu

|--| Seleksi sekolah - Lulus tepat waktu

|--| Seleksi reguler - Lulus tepat waktu

|--|Seleksi undangan - Lulus tepat waktu

|Sks 4 -22

|--|Seleksi mandiri - Lulus tepat waktu

|--|Seleksi reguler - tidak lulus tepat waktu

|--|Seleksi undangan - Lulus tepat waktu / tidak

lulus tepat waktu

|--|Seleksi disekolah - Lulus tepat waktu

Sedangkan untuk prosentase kelulusan mahasiswa berdasarkan jenis kelamin dapt dilihat pada tabel berikut

Tabel 4. Proses kelulusan berdasarkan jenis kelamin

\begin{tabular}{|c|c|c|c|}
\hline NO & $\begin{array}{c}\text { JENIS } \\
\text { KELAMIN }\end{array}$ & $\begin{array}{c}\text { LULUS TEPAT } \\
\text { WAKTU }\end{array}$ & $\begin{array}{c}\text { TIDAK LULUS TEPAT } \\
\text { WAKTU }\end{array}$ \\
\hline 1 & WANITA & $40 \%$ & $60 \%$ \\
\hline 2 & PRIA & $60 \%$ & $40 \%$ \\
\hline
\end{tabular}

\section{IV.KESIMPULAN}

Berdasarkan hasil perhiungan menggunakan algoritma ID3 pada data akademik mahasiswa AMIK Harapan Bangsa Surakarta tahun 2012-2013dan 2016-2017 didapatkan bahwa faktor utama penentu kelulusan mahasiswa tepat waktu adalah jenis kelamin. Sedangkan untuk faktor kedua dari jenis kelamin wanita adalah sks yang diambil untuk semester 4. Pada jenis kelamin pria faktor penentu selanjutnya adalah sks yang diambil pada semester 4 . Artinya faktor kedua pada masing- masing jenis kelamin adalah sama. Hal ini dapat menjadi perhatian bagi bagian akademik untuk berkordinasi dengan masing-masing pendamping akademik setiap angkatan yang mahasiswanya akan memasuki masa tugas akhir agar menyiapkan strategi khusus untuk mahasiswa tersebut. Prosentase yang paling besar untuk lulus tidak tepat waktu adalah jenis kelamin wanita. Sehingga mahasiswa dengan jenis kelamin wanita perlu mendapatkan penanganan khusus jika sudah menunjukan potensi tidak lulus tepat waktu.

\section{DAFTAR PUSTAKa}

[1] Andriani, A. (2012). Penerapan Algoritma C4.5 Pada Program Klasifikasi Mahasiswa Dropout. Seminar Nasional Matematika, 139-147. Retrieved from http://demo.pohonkeputusan.com/files/PENERAPAN

ALGORITMA C4.5 PADA PROGRAM KLASIFIKASI MAHASISWA DROPOUT.pdf?i=1

[2] Elmande, Y., \& Widodo, P. (2012). Pemilihan Criteria Splitting dalam Algoritma Iterative Dichotomiser 3 (ID3) untuk Penentuan Kualitas Beras: Studi Kasus Pada Perum Bulog Divre Lampung. Jurnal TELEMATIKA MKOM, 4(1).

[3] Fakhrurrifqi, M., \& Wardoyo, R. (2013). Perbandingan Algoritma Nearest Neighbour, C4. 5 dan LVQ untuk Klasifikasi Kemampuan Mahasiswa. IJCCS (Indonesian Journal of Computing and Cybernetics Systems), 7(2), 145-154.

[4] Lavanya, D., \& Rani, K. U. (2011). Performance Evaluation of Decision Tree Classifiers on Medical Datasets. International Journal of Computer Applications, 26(4), 1-4. https://doi.org/10.5120/30954247

[5] Mueller, M., dos Santos, V. G., \& Seuring, S. (2009). The contribution of environmental and social standards towards ensuring legitimacy in supply chain governance. Journal of Business Ethics, 89(4), 509-523. https://doi.org/10.1007/s10551-008-0013-9

[6] Nugroho, Y. S. (2014). Penerapan Algoritma C4.5 Untuk Klasifikasi Predikat Kelulusan Mahasiswa Fakultas Komunikasi Dan Informatika Universitas Muhammadiyah Surakarta. Prosiding Seminar Nasional Aplikasi Sains \& Teknologi (SNAST) 2014, (November), 1-6. https://doi.org/10.13140/RG.2.1.2734.8247

[7] Setiawan, B., Widjaja, R. S., Learning, D. T., Quinlan, R., Kapal, K., \& Belakang, L. (2009). Untuk Menentukan Kelaiklautan Kapal. Prosiding Seminar Nasional Manajemen Teknologi X, 1-7. https://doi.org/10.1186/1471-2164-15-579

[8] Slocum, M. (2012). Decision Making Using Id3 Algorithm. InSight RIVIER ACADEMIC JOURNAL, 8(2), 1-12.

[9] Ugulino, W., Cardador, D., \& Vega, K. (2012). Wearable Computing: Accelerometers ' Data, 52-53.

[10] Wu, X., \& Kumar, V. (2009), the top ten algorithms in data mining. (V. Kumar, Ed.). london: crc press. 